\title{
ANALYSIS OF EARNINGS PHESHAAREINIPORMATION IN PREDICTING SHARE PRICES IN THE COLOMBO STOCK EXCHANGE
}

By

A. A. ABDUL LATHIF 


\title{
ANALYSIS OF EARNINGS PER SHARE INFORMATION IN PREDICTING SHARE PRICES IN THE COLOMBO STOCK EXCHANGE
}

\author{
By \\ A.A. Abdul Lathif \\ Index No.GS/MC/460/98
}

A Dissertation submitted To The University of Sri Jayewardenepura In Partial Fulfillment of The Requirements For The Degree of Master of Science In Management.

\author{
M.Sc (Management) Programme \\ Faculty of Graduate Studies \\ University of Sri jayewardenepure \\ December 2005
}




\section{CERTIFICATION}

I hereby recommend that the thesis was prepared under my supervision by Abdul Azees Abdul Lathif (GS/MC/460/98) Tital 'Analysis of Earnings Per Share Information In predicting Share Prices In The Colombo Stock Exchange' has been accepted in partial fulfillment of the requirements for the degree of Master of Science in Management.

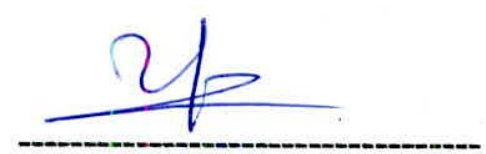

\section{(Dr.Y.K.Weerakoon Banda )}

Thesis Advisor

Approved by the Examining Committee
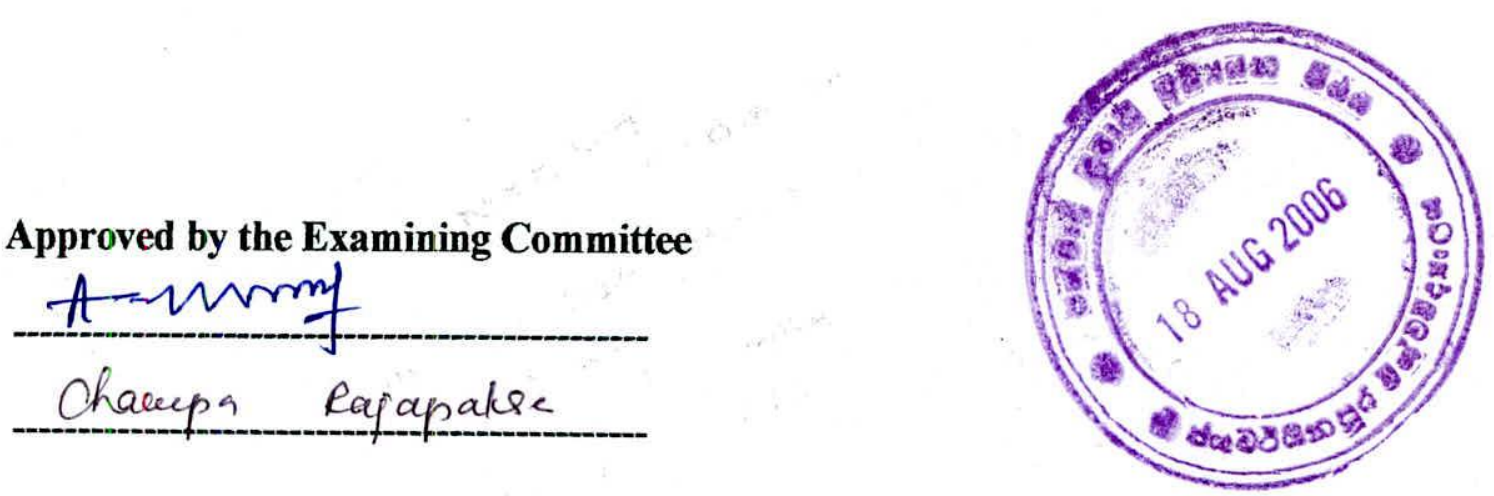

M.Sc (Management) Programme

Faculty of Graduate Studies

University of Sri jayewardenepure

Sri Lanka

December 2005 


\section{ACKNOWLEDGEMENTS}

I think it is my duty to pay gratitude to those who extended the fullest support towards my work on this thesis. Specially, I would like to express my sincere appreciation to my supervisor Dr.Y.K.Weerakoon Banda, Head, department of finance, University of Sri Jayewardenapura for his guidance and encouragement all throughout my work on this thesis.

I also wish to extend my special word of thanks to all lecturers of the course work of the M.Sc.( Management) program whose teaching enrich me in doing a task of this kind. Also my special remembrance with many thanks Dr.Kannedy D Gunawardana, coordinator of the M.Sc. (Management) program and the former coordinators Dr.S.W.Hirantha, Dr.H.H.D.N.P.Opatha, Dr.Bhadra Arachchige and Dr.Sampath Amaratunge for their encouragement and assistance throughout the program.

I wish to extend my thanks to Mr.Vinayagamoorthy Devadas- Senior Manager, Mr.Palitha Peris and Mr.Thushare Jayeratne, CSE executives who supported me in giving me the data. I am deeply grateful to Mrs.S.Safeena MG.Hassan senior Lecturer, University of South Eastern, Mr.H.M.Alisabri senior Lecturer, Dr.A.A.Azeez senior Lecturer Dr.M.J.M.Fazeel senior Lecturer, Dr.Ms.M.J.Fazeela Ahzan senior Lecturer University of Colombo for helping me to arrange my data set. Finally, I wish to thank my parents, my spouse, my daughters, my son for their sacrifices and dedication, patience and continuous encouragement shown during my studies.

\section{A.A.Abdul Lathif}




\begin{abstract}
This research aimed to study the impact of earning per share announcements on share prices in the Colombo stock exchange. The research problem focused here was "What level of market impact of earning per share announcements on the share prices." This research attempted to examine the impact of earning per share announcements on share prices in the Colombo Stock Exchange.
\end{abstract}

The sample consists of 280 earning per share announcements by 35 companies from 11 sectors listed in the Colombo stock exchange. The research covers eight years period from 1994 to 2001.To investigate the stock market response to earning per share announcement, the standard event study methodology is used. In this study the estimation of 100 days an event window of 21 days are used.

The analysis showed that, the Colombo Stock Exchange market is not efficient in the semi strong form sense. The study also concluded that earning per share announcements has no significant impact on stock prices. Since the results of this study indicate that the CSE is informationally inefficient so it has important implications for the investors, management of companies and stock market regulatory agencies. The investors could make use of reaction of earning per share announcements information to make decisions with regard to changes ( to buy or sell ) they have to make their portfolio in order to make profits or avoid potential losses. 


\section{TABLE OF CONTENTS}

page

ACKNOWLEDGEMENT

iii

ABSTRACT

iv

TABLE OF CONTENTS

v

LIST OF TABLES

vii

LIST OF FIGURES

ix

ABBREVATIONS

$x i$

\section{CHAPTER 1}

\section{INTRODUCTION}

1.1 Background of The Study 1

1.2 The Problem Statement 2

1.3 Objectives of The Study 3

1.4 Methodology 3

1.5 Significance of The Study 4

1.6 Limitations of The Study 4

1.7 Organization of The Study 4

\section{CHAPTER 2}

\section{REVIEW OF LITERATURE}

2.1 Introduction 5

2.2 Security Return 5

2.3 Earning Per Share 6

2.4 The Determination of Security Prices 7

2.5 Fundamental Analysis of Share Price Behaviour 8

$\begin{array}{ll}2.6 \text { Technical Analysis of Share Price Behaviour } & 10\end{array}$

2.7 Tool of Technical Analysis $\quad 11$

2.8 Theory of Efficient Market 13

2.8.1 Weak Form of Efficiency 15

$\begin{array}{ll}\text { 2.8.2 Semi- Strong Form of Efficiency } & 17\end{array}$ 
2.8.3 Strong Form of Efficiency 20

2.9 Price Reaction to Company Specific Information 21

2.10 Some Previous Studies on The Earning Announcements 22

2.11. Summary 24

\section{CHAPTER 3}

\section{METHODOLOGY}

3.1 Introduction 25

3.2 Hypotheses 25

3.3 Methodology 25

3.4 Sample Design $\quad 29$

\section{CHAPTER 4}

\section{DATA ANALYSIS AND DISCUSSION OF RESULTS}

4.1 Introduction 31

4.2 Impact of EPS Announcements at Overall Portfolio Level 31

4.3 Impact of EPS Announcements at Sector Level 33

4.4 Impact of EPS Announcements at Year wise 55

$\begin{array}{ll}4.5 \text { Summary } & 71\end{array}$

\section{CHAPTER 5}

5. SUMMARY AND CONCLUSIONS

5.1 Summary 73

5.2. Conclusion 75

5.3 Direction for Future Research $\quad 76$

$\begin{array}{ll}\text { References } & 77\end{array}$

$\begin{array}{ll}\text { Appendices } & 80\end{array}$ 


\section{LIST OF TABLES}

Table

Title

Page

01 Event study results of earning per share announcements for the portfolio of stock

02 Event study results of earning per share announcements for the portfolio for the Insurance and Banking Sector.

03 Event study results of earning per share announcements for the portfolio for the Beverage sector.

04 Event study results of earning per share announcements for the portfolio for the Chemicals and Pharmaceuticals.

05 Event study results of earning per share announcements for the portfolio for the Construction and Engineering Sector.

06 Event study results of earning per share announcements for the portfolio for the Diversified Holdings Sector.

07 Event study results of earning per share announcements for the portfolio for the Hotels and Travels Sector.

08 Event study results of earning per share announcements for the portfolio for the Land and Property Sector.

09 Event study results of earning per share announcements for the portfolio for the Motors Sector.

10 Event study results of earning per share announcements for the portfolio for the Trading Sector.

11 Event study results of earning per share announcements for the portfolio for the Services Sector.

12 Event study results of earning per share announcements for the portfolio for the Manufacturing Sector.

13 Event study results of earning per share announcements for the portfolio for the year 1994.

14 Event study results of earning per share announcements for the portfolio for the year 1995. 
15 Event study results of earning per share announcements for the portfolio for the year 1996.

16 Event study results of earning per share announcements for the portfolio for the year 1997.

17 Event study results of earning per share announcements for the portfolio for the 1998.

18 Event study results of earning per share announcements for the portfolio for the year 1999.

19 Event study results of earning per share announcements for the portfolio for the 2000 .

20 Event study results of earning per share announcements for the portfolio for the year 2001 . 


\section{LIST OF GRAPH}

Graph

Title

01 Behaviour of CAAR of Earning Per Share Announcements During the test Period for the Portfolio level.

02 Behaviour of CAAR of Earning Per Share Announcements During the test Period for the Insurance and Banking Sector.

03 Behaviour of CAAR of Earning Per Share Announcements During the test Period for the Beverage sector .

04 Behaviour of CAAR of Earning Per Share Announcements During the test Period for the Chemicals and Pharmaceuticals Sector.

05 Behaviour of CAAR of Earning Per Share Announcements During the test Period for the Construction and Engineering Sector.

06 Behaviour of CAAR of Earning Per Share Announcements During the test Period for the Diversifed Holdings Sector.

07 Behaviour of CAAR of Earning Per Share Announcements During the test Period for the Hotels and Travels Sector.

08 Behaviour of CAAR of Earning Per Share Announcements During the test Period for the Land and property Sector.

09 Behaviour of CAAR of Earning Per Share Announcements During the test Period for the Motors Sector.

10 Behaviour of CAAR of Earning Per Share Announcements During the test Period for the Trading Sector.

11 Behaviour of CAAR of Earning Per Share Announcements During the test Period for the Services Sector.

12 Behaviour of CAAR of Earning Per Share Announcements During the test Period for the Manufacturing Sector.

13 Behaviour of CAAR of Earning Per Share Announcements During the test Period for the year 1994.

14 Behaviour of CAAR of Earning Per Share Announcements During the test Period for the year 1995 . 
15 Behaviour of CAAR of Earning Per Share Announcements During the test Period for the year 1996.

16 Behaviour of CAAR of Earning Per Share Announcements During the test Period for the year 1997.

17 Behaviour of CAAR of Earning Per Share Announcements During the test Period for the year 1998 .

18 Behaviour of CAAR of Earning Per Share Announcements During the test Period for the 1999 .

19 Behaviour of CAAR of Earning Per Share Announcements During the test Period for the 2000 .

20 Behaviour of CAAR of Earning Per Share Announcements During the test Period for the 2001 . 


\section{LIST OF ABBREVIATIONS}

\begin{tabular}{|c|c|}
\hline AAR & -Average Abnormal Returns \\
\hline $\mathrm{AR}$ & -Abnormal Returns \\
\hline ASPI & -All Share Price Index \\
\hline MPI / SPI & -Milanka / Sensitive Price Index \\
\hline CAAR & -Cumulative Average Abnormal Returns \\
\hline CSE & -Colombo Stock Exchange \\
\hline $\mathrm{EMH}$ & -Efficient Market Hypothesis \\
\hline NYSE & -New York Stock Exchange \\
\hline USA & -United State of America \\
\hline UK & -United Kingdom \\
\hline SEC & -Security and Exchange Commission \\
\hline DPS & -Dividend Per Share \\
\hline EPS & -Earning Per Share \\
\hline T-STAT & -T- Statistics \\
\hline STD & -Standard Deviation \\
\hline BANK & -Banks Finance and Insurance \\
\hline BEVERAGE & -Beverage Food and Tobacco \\
\hline CHEMICALS & -Chemicals and Pharmaceuticals \\
\hline CONSTRUCTION & -Construction and Engineering \\
\hline DIVERSIFIED & -Diversified Holdings \\
\hline HOTEL & -Hotels and Travels \\
\hline LAND & -Land and Property \\
\hline
\end{tabular}




\section{CHAPTER 1 \\ INTRODUCTION}

\subsection{Background of the Study}

The investors are expecting optimum return from their investment through price gain and dividends. They are interested in price reactive information. The information needed by the share market can be classified into two broad categories: (i) internal and (ii) external information. Internal information consists of data and events made public by companies concerning their operations. It mainly takes the form of interim and annual financial statements to shareholders, and statements of the officers and managers of the firm. The financial statements comprise of profit and loss Account, Balance sheet and cash flow statement. Financial statement information is one of many potential sources that the capital markets may use in revising the values of common stock.

The questionnaire survey conducted by Chang, Most and Brian (1983) in USA, UK and New Zealand has provided strong evidence in support of this view. In their study institutional investors, individual investors and financial analysts in all the three countries gave the most consistently high ranking for the corporate annual reports as the source of information. Other than the financial statements, there are several key categories of firm specific internal information that are influencing the market's decisions on price of a particular share ${ }^{1}$. The impact of most of these firm specific information on prices of shares have been extensively studied in financial literature.

The empirical studies on market price behaviour have yielded theory of market efficiency. Research evidences show that in many of the capital markets, the forces which set the prices of individual shares cause pricing efficiency to occur. "Efficiency" in this context means that all available information concerning a particular security's future prospects is at all times fully and rationally reflected in the share prices. In the literature a

\footnotetext{
1 These categories of firm oriented information can be classified as follows: earning related announcements, forecasted earning announcements, dividend announcements, financing announcements, investment announcements, labor and legal announcements, marketing, production and sales announcements and merger and takeover announcements.
} 
distinction is made between three levels of efficiency, each level relating to a specific set of information. These are namely, the weak form of the efficient market hypothesis, the semi-strong form and the strong form.

So far we have discussed share market reaction to internal information. Other than the internal information external information such as economical and industrial factors also have an effect on share prices. King (1966) observed that, on average, over half the variations in a share's price could be attributed to the general economic and industry influences of the country. These influences are common to all shares traded in the stock exchange. Therefore, the market performance is directly related to overall economic performance and the particular industry performance. That is, the success of the economy will ultimately depend on the success of the overall market. Therefore financial managers should know the ways in which securities are traded and priced in the capital markets. They should also know the procedures to be followed in issuing securities.

Stock market analysts have found that changes in capital structure have impacts on earning per share (EPS). Share price, price earning ratio (PE ratio) and cost of capital of a company. It is the objective of every investor to drive maximum return from investments.

\subsection{Problem Statement}

Stock price behavior is rapidly changing during the last few years (ASPI/MPI lines have grown rapidly during the time period from 1990 to 1994 and decreased from the time period 1995 to 2001). Examining these changing situations carefully, though, some listed companies' shows the favorable returns throughout the year their market share prices have come down. The problem is why those share prices have come down even though their companies' show the higher returns? In case of foreign stock markets, researchers have identified the answers to these questions. In the long run, they identified some factors, which affect share prices. In Sri Lankan situation some factors have also considerably changed since the last decade. From 1994 the stock prices have decreased continuously. In this context, therefore, some factors affect the stock market activities 
day by day. Hence stock returns in the stock market in Sri Lanka presents a veritable problem to be reckoned with which might not yet been addressed.

In a semi-strong form efficient market all the publicly available information should be reflected in share prices instantaneously. Therefore, if the CSE is semi-strong form efficient, we should be able to observe a quick and unbiased price reaction to EPS announcements by studying price reaction of shares traded at the Colombo Stock Exchange to the specific information of announcement, and awareness can be created about share price behaviour among investors, management of the companies, brokers and companies in particular and public in general.

\subsection{Objectives of the Study}

The main objective of this study,

1. To examine the impact of earning per share announcements on share prices in the Colombo Stock Exchange (CSE).

2. To examine the market efficiency of the Sri Lanka Colombo Stock Exchange (CSE).

\subsection{Methodology}

For the study the secondary data are used as a major source of data collection. The data are obtained from the Colombo stock Exchange and other relevant sources. For the purpose of this research the sample consists of 280 earning per share announcements by 35 companies from 11 sectors listed in the Colombo stock exchange. The research covers an eight year period from 1994 to 2001. This study employs well-known event study methodology to examine the stock price reaction to the information contained in EPS announcements by companies. An event study is the name given to an empirical investigation of the relationship between security prices and firm specific economic events. Most event studies have focused on the behavior of share prices in order to test whether their stochastic behavior is affected by the disclosure of firm specific events.

To investigate the stock market response to earning per share announcements, the standard event study methodology is employed. In this study an estimation of 100days an 